\title{
Um Breve Olhar Sobre a Questão Migratória no Japão
}

\author{
Aline Chianca Dantas ${ }^{1}$
}

\section{RESUMO}

Este estudo reveste-se do interesse em realizar uma breve análise da questão migratória no Estado japonês, com objetivo de problematizá-la e ensejar maiores discussões, pensando as relações cooperativas entre países. Sendo assim, observa-se, inicialmente, a característica da política externa japonesa e, em seguida, três casos típicos de migração no Japão, quais sejam: retornados, deslocados ambientais e refugiados.

Palavras-chave: Migrações; Japão; Cooperação Internacional.

0 presente estudo de caso tem como objetivo analisar, brevemente, a situação das migrações envolvendo o Japão. Nesse sentido, é desenvolvido um pequeno histórico sobre a política externa japonesa, compreendendo as implicações para os assuntos ligados às migrações. Em seguida, são apresentadas três situações típicas de migrações dentro do território japonês, quais sejam: retornados (dekasseguis), deslocados ambientais e refugiados. Por fim, são delineados soluções e abordagens teóricas possíveis para as problemáticas.

O Japão começou seu período de abertura política somente no século XIX, mas, logo depois, iniciou um processo expansionista que culminou na derrota durante a Segunda Guerra Mundial e em uma política externa essencialmente focada no desenvolvimento econômico do país. Sendo assim, as preocupações com as questões migratórias foram tardias, observando-se o porquê de existirem políticas imigratórias restritivas, separação bastante forte entre o japonês e o estrangeiro, assinatura de normas internacionais e criação de leis referentes à migração em momentos mais

1 Mestranda em Relações Internacionais pela Universidade Estadual da Paraíba, graduada em Relações Internacionais pela Universidade Estadual da Paraíba e graduada em Direito pela Universidade Federal da Paraíba. Membro do Grupo de Estudos e Pesquisa em Ásia-Pacífico da Universidade Estadual da Paraíba GEPAP. 
recentes da história. A década de 1990, por outro lado, vai representar um período de tentativa de redefinição de poder do Japão, repercutindo em um maior envolvimento do país nas questões relevantes para a comunidade internacional, não obstante ainda haja necessidade de uma maior cooperação internacional e de políticas de integração social (RODRIGUES e KINJYO, 2010).

Passa-se a discutir, então, o primeiro tipo de migração: os retornados. Esse é um caso típico japonês e tem bastante relação com os valores culturais japoneses e a forma como os descendentes de um japonês emigrante consideram-se ligados ao Japão, acreditando-se japoneses de segunda e terceira gerações em vez de nacionais de outros países. Dessa forma, embora muitos japoneses tenham emigrado do Japão durante o século XX, devido aos conflitos regionais e às Guerras Mundiais, a partir da década de 1980, e, especialmente, 1990, percebe-se o forte retorno dos nikkeis (descendentes de japoneses) latino-americanos para o Japão, possibilitado de maneira mais ampla pela Lei japonesa de imigração de 1990. A priori, esses japoneses eram vistos como mão-de-obra temporária, apenas nos anos 2000 é que esses nikkeis passaram a ser considerados residentes japoneses, mas ainda há muito o que se avançar em termos de garantias a esses indivíduos (ISHI, 2010; GRADILONE, 2010). Assim, os retornados podem ser considerados migrantes voluntários econômicos.

Já a presença de deslocados ambientais, no território japonês, justifica-se pela frequente ocorrência de desastres naturais no país. Mas, geralmente, os deslocamentos acontecem dentro do Japão e o país possui uma forte estrutura de reconstrução pósdesastres, que, inclusive, movimenta a economia e a promoção da relação da população com as Forças de Autodefesa (ORIKI, 2011). Esses migrantes são incorporados dentro da classificação de migração forçada (CASTLES, 2005, p. 20).

Quanto aos refugiados, percebe-se uma fragilidade política enorme, em virtude de o Japão, historicamente, ter enviado emigrantes e, raramente, ter recebido imigrantes, refletindo no surgimento tardio de políticas migratórias, além do empecilho gerado pelas condições especiais que o país acredita possuir, como, excesso de população, barreira linguística e sociedade monoétnica. Assim, após críticas internacionais, o Japão adotou a Convenção de 1951 e o Protocolo de 1967 da ONU em 
1981. Apesar disso, o país ainda continuou mantendo certa política isolacionista (RODRIGUES e KINJYO, 2010).

É relevante ressaltar que não existe nenhuma preocupação em relação aos refugiados, na Constituição japonesa de 1946 e que, apenas em 1982, foi criada a Lei de Controle de Imigração e Ato de Reconhecimento do Refugiado, que é controlada e aplicada pelo Departamento de Imigração do Ministério da Justiça. O problema é que esse órgão é responsável pelas políticas de imigração, bem como pelo reconhecimento de refugiados, o que dificulta a solicitação e a concessão de refúgio. Ademais, a definição de refugiados para o Japão é a da Convenção de 1951, não abarcando certas situações que outros países, mais avançados na questão migratória, o fazem, ao utilizarem de concepções mais amplas para reconhecimento de refugiados. Ainda, há um período para solicitação de refúgio, que, desde 2005, é de 180 dias, mas antes era de 60 dias, obstando a obtenção do refúgio (RODRIGUES e KINJYO, 2010). Assim, há discussões sobre essa regra japonesa frente ao princípio do non refoulement, que se baseia na proibição de um país acolhedor devolver o refugiado ao Estado de perseguição (PACÍFICO, 2010, p. 41).

Dessa forma, segundo dados do Ministério da Justiça Japonês, entre 1982 e 2008, 410 pessoas foram reconhecidas como refugiadas e 3162 tiveram o status negado (RODRIGUES e KINJYO, 2010). Uma solução apontada pela literatura para a mudança desse quadro é a separação da política migratória de uma política de proteção dos refugiados, além de uma cooperação com os países que enviam esses refugiados, pois se o Japão tem limitações territoriais e culturais para recepcionar esses refugiados, seria interessante criar condições nos países vizinhos para que essas pessoas pudessem permanecer em seus países de origem (RODRIGUES e KINJYO, 2010; BETTS, 2006). Nesses termos, o Japão deveria intensificar suas relações com os países que, segundo dados da ACNUR de 2012, estão entre os dez que mais enviam refugiados para o Japão, ou seja, Turquia, Nepal, Miammar, Paquistão, Sri Lanka, Bangladesh, Camarões, Índia, Nigéria e Irã.

Portanto, conclui-se que o Japão ainda possui muito que avançar em termos de políticas migratórias e, especialmente, na questão dos refugiados, necessitando primar por políticas mais amplas e integracionistas, por maiores cooperações internacionais, para além da simples ajuda financeira (YAMAWAKI, 2010; BETTS, 2006). 


\section{Referências Bibliográficas}

BETTS, Alexander. Conceptualising Interconnections in Global Governance: the case of refugee protection. Working Paper Series. RSC Working Paper 38. Oxford: RSC/QEH/IDC/ University of Oxford, 2006.

GRANDILONE, Eduardo. Discurso do Embaixador. In: 20 anos dos brasileiros no Japão. Brasília: FUNAG, 2010.

ISHI, Angelo. Reflexôes sobre os 20 anos do movimento "dekassegui" - a perspectiva de um brasileiro radicado no Japão. In: 20 anos dos brasileiros no Japão. Brasília: FUNAG, 2010.

ORIKI, Ryoichi. The Role of Self Defense Forces (SDF) in Response to the Great East Japan Earthquake, 2011.

PACÍFICO, Andrea Pacheco. 2010. O Capital Social dos Refugiados: Bagagem Cultural e Políticas Públicas. Maceió: Edufal.

RODRIGUES, Viviane Mozine; KINJYO, Eyla Miyuki. As políticas contemporâneas aplicadas no Brasil e no Japão sobre o Estatuto de Refugiados. In: Revista Internacional de Mobilidade Humana. Brasília, Ano XVIII, № 35, jul/dez 2010, pp. 211-229.

UNHCR- United Nations High Commissioner for Refugees. Disponível em: <http://www.unhcr.org/507c000e9.html>. Acesso em: 16 nov. 2012.

YAMAWAKI, Keizo. Questões atuais relativas à política dos estrangeiros no Japão. In: 20 anos dos brasileiros no Japão. Brasília: FUNAG, 2010. 